\title{
EVALUASI PELAKSANAAN PROGRAM SATU MILYAR SATU KECAMATAN (SAMISAKE) DI KECAMATAN DEPATI TUJUH KABUPATEN KERINCI PROVINSI JAMBI TAHUN 2014
}

\author{
PEBI JULIANTO \\ Pascasarjana Magister Manajemen Sekolah Tinggi Ilmu Ekonomi \\ Keuangan Perbankan dan Pembangunan Padang \\ juliantopebi2@gmail.com
}

\begin{abstract}
Samisake programme as a umbrella of constructor region programme and ward off the proverty which operated based on regulation of governor about increase ward off of proverty. This research has direction for knowing about process of Implementation Satu Milyar Satu Kecamatan (Samisake) Programme, and the result. This research is descriptive evaluative research is research which give an attention for implementation process of a program. Then focus to a relation causally what is the program suitable with the result or its goal which is wanted. Then from the research can also as a description of the advantages and shortages this programme, for doing an evaluation in order to this wisdom/programme can be better. This programme at Depati Tujuh can implemented in activities, like as Bedah Rumah, Beasiswa, Bantuan Modal, Alsintan, and Pelatihan Menjahit. Satu Milyar Satu Kecamatan Programme is proper to hold out because in the implementation very give benefit to society, via this programme which support activities social and economy of society.
\end{abstract}

\section{PENDAHULUAN}

Program Satu Milyar Satu Kecamatan menekankan pelaksanaan penguatan kelembagaan pembangunan masyarakat di tingkat lokal berdasarkan prinsip pembangunan yang pasrtisipatif. Bantuan Samisake mengutamakan pembangunan yang dilakukan panitia lapangan kecamatan dan dilaksanakan langsung oleh penerima bantuan. Melalui Samisake, bantuan langsung berupa hibah diberikan langsung kepada penerima bantuan melalui camat dan telah diverifikasi oleh panitia di kantor camat dengan peruntukan bagi investasi sosial, investasi ekonomi yang menghasilkan dana bergulir dan kegiatan peningkatan kemampuan masyarakat dalam penyelenggaraan pembangunan di tingkat lokal (capacity building and institution building).

Program Satu Milyar Satu Kecamatan (Samisake) dalam kenyataannya dilaksanakan di seluruh wilayah di Provinsi Jambi sejak tahun anggaran 2011. Program Satu Milyar Satu Kecamatan (Samisake) dilaksanakan di seluruh kecamatan yang 
berada di kawasan geografis wilayah Pemerintah Provinsi Jambi.

Program Samisake digunakan untuk kegiatan-kegiatan yang pro rakyat pada masyarakat seperti: Bedah Rumah, Beasiswa, Jamkesmasda Provinsi, Penerbitan sertifikat tanah gratis, Pengadaan kendaraan roda tiga, Pengadaan alat mesin pertanian (Alsintan), Bantuan modal, Sambungan listrik, Pelatihan tenaga kerja, Meningkatkan sosial ekonomi masyarakat. Sedangkan kegiatankegiatan yang terlaksana pada Kecamatan Depati VII Kabupaten Kerinci Provinsi Jambi untuk Program Samisake tahun 2014 adalah Bedah Rumah (56,8\%) , Beasiswa (9,5\%), Jamkesda Provinsi (10,5\%), Pengadaan alat mesin pertanian (Alsintan) $(11,2 \%)$, Bantuan modal $(7,8 \%)$ dan Pelatihan tenaga kerja $(4,2 \%)$.

Mengevaluasi kinerja pelaksanaan Program Satu Milyar Satu Kecamatan (Samisake) bukanlah kegiatan satu kali. Evaluasi kinerja adalah proses yang mencakup perencanaan sejak awal dan memeliharanya secara teratur. Perencanaan kinerja membutuhkan waktu dan dituntut pula satu pemikiran.

Program Satu Milyar Satu Kecamatan (Samisake) sebagai sebuah program yang bertujuan untuk penanggulangan masalah kemiskinan dan memberdayakan masyarakat, menjadi penting sebagai sebuah kebijakan negara. Program ini diharapkan mampu memberikan sebuah konsep pembangunan yang berbasis pada pemberdayaan. Program Satu Milyar Satu Kecamatan (Samisake) mencakup aspek kegiatan ekonomi, kegiatan fisik, dan aspek pemberdayaan masyarakat di masing-masing wilayah program. Dari hal tersebut maka akan dilakukan kajian terhadap implementasi
Program Satu Milyar Satu Kecamatan (Samisake) di Kecamatan Depati Tujuh, Kabupaten Kerinci, Provinsi Jambi. Apakah implementasinya sudah sesuai dengan prinsip - prinsip program tersebut? Sebagai sebuah kebijakan tentunya Program Satu Milyar Satu Kecamatan (Samisake) mempunyai ketentuan yang harus dipenuhi dalam pelaksanaannya.

Pemberdayaan masyarakat sebagai salah satu tujuan dari Program Satu Milyar Satu Kecamatan (Samisake) juga dapat dilakukan penilaian. Bagaimanakan proses pemberdayaan masyarakat yang ada di dalam Program Satu Milyar Satu Kecamatan (Samisake). Pada akhirnya, pelaksanaan Program Satu Milyar Satu Kecamatan (Samisake) yang telah dilaksanakan sejak tahun 2012, dengan penguatan ekonomi produktif lokal diharapkan benar-benar memberikan peningkatan kemampuan masyarakat dan aparat dalam penyelenggaraan pembangunan di tingkat lokal. Dari hal tersebut di atas dilakukan kajian lebih mendalam tentang proses pelaksanaan Program Satu Milyar Satu Kecamatan (Samisake) tahun 2014 yang dilaksanakan di Kecamatan Depati Tujuh, Kabupaten Kerinci, Provinsi Jambi.

Pada kenyataanya bahwa masih tidak meratanya sarana dan prasarana yang menunjang kegiatan sosial ekonomi warga masyarakat, khususnya di Kecamatan Depati Tujuh. Kurangnya apresiasi dan partisipasi masyarakat dalam pembangunan tingkat lokal khususnya desa dan kecamatan, sebagai akibat paradigma pembangunan model 'top down' yang dipergunakan dalam pendekatan pembangunan di masyarakat. Pada Program Satu Milyar Satu Kecamatan (Samisake) di Kecamatan Depati Tujuh yang memberikan hibah 
terhadap pelaksanaan sarana dan prasarana yang mendukung kegiatan sosial ekonomi masyarakat, bantuan dana yang dapat dipergunakan untuk peningkatan kapasitas masyarakat.

\section{SOROTAN PENELITIAN SEBELUMNYA DAN TEORI}

Penelitian terduhulu diambil dari penelitian yang dilakukan oleh Warih Budiyono Setyawan dengan judul Evaluasi Proses Pelaksanaan Program Pengembangan Kecamatan (PPK) di Kecamatan Karangmojo Kabupaten Gunungkidul. Program penanggulangan kemiskinan dirasakan belum terpadu, terarah dan berkesinambungan maka dikembangkan Program Pengembangan Kecamatan (PPK) untuk mencapainya. Program Pengembangan Kecamatan (PPK) dilaksanakan berdasarkan prinsip pembangunan partisipatif. Pada akhirnya sebuah program yang dilaksanakan akan dicari kesesuaiannya dengan konsep program itu sendiri. Apakah Program Pengembangan Kecamatan (PPK) di Kecamatan Karangmojo telah dilaksanakan sesuai dengan konsepnya. Program Pengembangan Kecamatan (PPK) secara keseluruhan di Indonesia dimulai pada Tahun 1998/1999 sebagai sebuah pengembangan dari program penanggulangan kemiskinan atau Program Inpres Desa Tertinggal. Program Pengembangan Kecamatan (PPK) di Kecamatan Karangmojo dilaksanakan mulai Tahun 2001. Di Kecamatan Karangmojo, Program Pengembangan Kecamatan (PPK) dilaksanakan sejak tahun 2001sampai tahun 2004 di 9 (sembilan) desa dalam wilayah Kecamatan Karangmojo. Desadesa tersebut adalah Bendungan,
Wiladeg, Bejiharjo, Kelor, Ngawis, Ngipak, Gedangrejo, Karangmojo dan Jatiayu. Bantuan tersebut ilokasikan untuk kegiatan pembangunan prasarana fisik yang menunjang kegiatan sosial ekonomi masyarakat dan kegiatan ekonomi yaitu kegiatan simpan pinjam dan bantuan modal usaha. Bantuan yang dikelola melalui program pembangunan ekonomi (dana bergulir). Dana yang digulirkan akan terus digunakan sebagai pembiayaan ekonomi produktif bagi warga masyarakat selanjutnya. Dana bergulir tersebut dikelola dalam sistem simpan pinjam dana bergullir. Kelompok masyarakat yang memanfaatkan dana simpan pinjam tersebut wajib mengembalikan kepada pengelola di masing - masing desa. Hal tersebut dimaksudkan untuk manjaga kelangsungan perguliran yang nantinya akan dinikmati seluruh warga masyarakat yang membutuhkan untuk membiayai investasi ekonomi yang dilaksanakan dalam kegiatan PPK.

Berdasarkan hal tersebut dilakukan evaluasi dengan penelitian Proses Pelaksanaan Program Pengembangan Kecamatan (PPK) di Kecamatan Karangmojo Kabupaten Gunungkidul untuk melakukan kajian terhadap hasil pelaksanaan program - program, baik program fisik, program ekonomi produktif dan penguatan kapasitas masyarakat yang merupakan komponen Program Pengembangan Kecamatan (PPK) dan melakukan analisis terhadap kesesuaian konsep dan implementasi Program Pengembangan Kecamatan (PPK) di Kecamatan Karangmojo. Penelitian ini pada akhirnya didapat kesimpulan bahwa PPK di Kecamatan Karangmojo telah berjalan dengan berpegang pada prinsip- prinsip program itu sendiri. Proses pelaksanaan Program Pengembangan Kecamatan (PPK) yang 
berpegang pada prinsip desentralisasi, keterbukaan, keterlibatan orang miskin dan keterlibatan perempuan serta pelestarian akan memungkinkan tercapainya tujuan program terhadap penguatan kapasitas masyarakat di kecamatan Karangmojo. Program Pengembangan Kecamatan (PPK) di Kecamatan Karangmojo juga telah dapat membangun prasarana fisik yang mendukung kegiatan sosial ekonomi masyarakat, berupa jalan, los pasar, jembatan, walaupun belum dapat merata di setiap desa atau dusun.Untuk kegiatan ekonomi berupa pemberian bantuan modal untuk usaha ekonomi produktif dan simpan pinjam, telah mampu membantu masyarakat dalam meningkatkan kesejahteraan. Melalui bantuan kegiatan fisik dan ekonomi maka PPK sebagai salah satu program yang berbasis pemberdayaan, akan memberikan kemudahan akses sosial ekonomi yang pada akhirnya memberikan kondisi perbaikan kesejahteraan sesuai dengan kemampuan masyarakat itu sendiri. Walaupun belum dapat dikatakan dengan adanya pelaksanaan Program Pengembangan Kecamatan (PPK) di Kecamatan Karangmojo telah mampu mengubah secara langsung dan dalam waktu yang singkat terhadap tingkat kemiskinan namun dimungkinkan akan mendorong ke kehidupan yang lebih baik dan secara pelan namun pasti terwujud. Pada akhirnya PPK harus dipertahankan sebagai sebuah program pembangunan yang berbasis pemberdayaan dan partisipatif.

\section{PENDEKATAN PENELITIAN}

Pendekatan yang digunakan dalam penelitian ini menggunakan pendekatan kualitatif atas fenomena yang ada di lingkup penelitian. Penelitian kualitatif menekankan tujuan eksploratif, yaitu suatu upaya untuk menjelaskan bagaimana fenomena suatu kegiatan terjadi dalam masyarakat yang sedang diteliti. Pendekatan kualitatif adalah suatu proses penelitian untuk memahami permasalahan manusia (sosial) dengan cara menjelaskan informasi dari informan secara terperinci dan disusun dalam sebuah latar ilmiah (Muhammad; 1999:34). Dalam penelitian ini pemahaman yang digunakan adalah untuk mengetahui dan menjelaskan bagaimana pelaksanaan Program Satu Milyar Satu Kecamatan (Samisake) di Kecamatan Depati Tujuh Kabupaten Kerinci. Hal tersebut dapat dipergunakan dalam mengevaluasi terhadap pelaksanaan Program Satu Milyar Satu Kecamatan (Samisake) di Kecamatan Depati Tujuh Kabupaten Kerinci.

Menurut Danin (2002:54) penelitian kualitatif mempunyai setting alami sebagai sumber data langsung. Penelitian kualitatif menggunakan setting alamiah atau pada konteks dari suatu keutuhan (entity) untuk pengumpulan data. (Moleong:1994:63). Data yang terkumpul dalam bentuk kata-kata dan gambar-gambar. Penelitian lebih menekankan pada proses kerja seluruh fenomena yang dihadapi dan diterjemahkan dalam kegiatan seharihari. Fokus utama penelaahan terkait langsung dengan kehidupan manusia. Penggunaan data kuantitatif dalam penelitian ini digunakan untuk mendukung hasil analisis.

\section{METODOLOGI PELAKSANAAN PENELITIAN}

Studi Evaluasi kebijakan pada prinsipnya berusaha memahami apa yang senyatanya terjadi (what happening) pada saat sebuah 
kebijakan/program diformulasikan sampai pada saat pelaksanaan kebijakan/program dilaksanakan sampai selesai. Studi ini juga memberikan analisa terhadap masalah-masalah yang timbul.

Dengan demikian studi evaluasi ini difokuskan pada hubungan kausal dengan outcome atau dampak kebijakan/program dan keberhasilan kebijakan/program tersebut. Dengan demikian definisi keberhasilan diukur dari proses pelaksanaan kebijakan/program dan sasaran program (beneficiaries) serta dampak yang ditimbulkan.

Penelitian ini merupakan penelitian deskriptif evaluatif yaitu penelitian yang memberikan perhatian kepada proses pelaksanaan satu kebijakan atau program. Dari hal tersebut kemudian ditekankan pada hubungan secara kausal, artinya apakah kebijaksanaan/program tersebut (Program Satu Milyar Satu Kecamatan) sesuai dengan hasil atau tujuan yang ingin dicapai. Kemudian dari penelitian tersebut juga dapat dideskripsikan kelebihan serta kekurangan kebijakan/ program, untuk dilakukan evaluasi agar kebijakan/program dapat semakin baik.

Metode penelitian ini nantinya akan menguraikan proses pelaksanaan Program Satu Milyar Satu Kecamatan (Samisake), artinya melihat apakah kebijakan/program itu sesuai dengan kriteria/petunjuk yang telah ditentukan, apakah kebijakan/program tersebut tepat sasaran, sesuai target yang ditentukan, apakah kekurangan dari kebijakan/ program yang telah dijalankan.

\section{TEKNIK SAMPLING}

Untuk mengumpulkan data primer dapat digunakan teknik sampling (teknik pengambilan sampel). Sampel adalah sebagian dari jumlah dan karakteristik yang dimiliki oleh populasi tersebut (Moleong, 1994:220). Bila populasi besar, dan peneliti tidak mungkin mempelajari semua yang ada pada populasi, misalnya karena keterbatasan dana, tenaga dan waktu, maka peneliti dapat menggunakan sampel yang diambil dari populasi itu.

Untuk itu dalam penelitian ini menggunakan teknik purposive sampling. Ciri-ciri teknik purposive sampling adalah (Moleong, 1994:223):

a. Pemilihan sampel secara berurutan dengan tujuan memperoleh variasi sebanyakbanyaknya yang hanya dapat dicapai bila pemilihan satuan sampel sebelumnya sudah dijaring dan dianalisis. Setiap satuan berikutnya dapat dipilih untuk memperluas informasi yang telah diperoleh sebelumnya sehingga dapat dipertentangkan atau diisi adanya kesenjangan informasi yang ditemui;

b. Penyesuaian berkelanjutan dari sampel, pada mulanya setiap sampel dapat sama kegunaannya, namun semakin banyak informasi dan semakin dalam maka sampelsampel yang dipilih atas dasar fokus penelitian.

c. Jika sudah terjadi pengulangan informasi, pemilihan sampel dihentikan. Faktor yang mempengaruhi pemilihan teknik ini adalah:

d. Mempermudah dalam mencari responden yang representatif pada populasinya dan menguasai objek studi, sehingga dapat menghemat waktu dan biaya.

e. Diperoleh responden yang benar- benar memahami, atau mengikuti mekanisme atau tahapan kebijakan Program Satu Milyar Satu Kecamatan (Samisake) di Kecamatan Depati Tujuh Kabupaten Kerinci. 
Pengambilan sampel dalam penelitian ini berupa tokoh kunci (key person) yang dipercaya memiliki karakteristik sampel yang diinginkan. Tokoh-tokoh kunci yang diambil berasal dari pihak masyarakat dan pihak pemerintah desa dan kecamatan.

Untuk mengetahui karakteristik penerima bantuan diberikan kuesioner sebanyak 20 (dua puluh) orang yang diambil dari masing-masing desa 2 (dua) orang.

Kemudian dilakukan juga wawancara terhadap masyarakat umum yang tidak masuk dalam kelompok masyarakat dan dimungkinkan menerima bantuan non ekonomi (prasarana) sebanyak 16 (enam belas) orang. Terhadap tokoh masyarakat juga dilakukan wawancara yang bertujuan menggali informasi tentang proses-proses yang terjadi dalam pelaksanaan Samisake yang terjadi di masyarakat. Tokoh masyarakat yang di wawancara masing-masing desa 1 (satu) orang dari 20 (dua puluh) desa di Kecamatan Depati Tujuh. Tokoh masyarakat yang diwawancarai dapat diambil dari unsur Badan Perwakilan Desa (BPD) atau tokoh-tokoh masyarakat lainnya yang dipandang representatif dalam kegiatan Samisake. Wawancara juga dilaksanakan terhadap pemerintah desa dan pemerintah kecamatan. Pemerintah desa dilakukan wawancara sebanyak 20 (dua puluh) kepala desa dengan berdasar jumlah desa di Kecamatan Depati Tujuh 20 (dua puluh) desa.

Wawancara yang dilakukan adalah sebagai sarana untuk memperoleh gambaran riil tentang proses pelaksanaan program. Wawancara terhadap unsur masyarakat adalah untuk melihat gambaran pelaksanaan program dari perspektif masyarakat sebagai penerima bantuan, sedangkan wawancara terhadap unsur pemerintah desa dan kecamatan adalah untuk melihat pelaksanaan program dari perspektif pemerintah sebagai pengelola program.

\section{Hasil-hasil kegiatan dalam Pelaksanaan Program Samisake di Kecamatan Depati Tujuh tahun 2014}

Alokasi dana Program Samisake sselama tahun anggaran 2014 adalah sebagai bentuk tabel berikut :

Tabel 4.3

Program Samisake di Kecamatan Depati Tujuh Tahun 2014

\begin{tabular}{cccc}
\hline \multirow{2}{*}{ No } & \multirow{2}{*}{$\begin{array}{c}\text { Nama } \\
\text { Kegiatan }\end{array}$} & \multicolumn{2}{c}{ Anggaran } \\
\cline { 3 - 4 } & Tahun 2014 & \% \\
\hline 1 & Bedah Rumah & 540.000 .000 & 56,8 \\
2 & Beasiswa & 90.000 .000 & 9,5 \\
3 & UMKM & 74.000 .000 & 7,8 \\
4 & Alsintan & 106.000 .000 & 11,2 \\
5 & Pelatihan & 40.000 .000 & 4,2 \\
6 & Jamkesda & 100.000 .000 & 10,5 \\
\hline Sumber : Bappeda & Kabupaten & Kerinci \\
data diolah &
\end{tabular}

1. Kegiatan Bedah Rumah

Kegiatan bedah rumah pada Kecamatan Depati Tujuh pada tahun 2014 dapat membedahkan rumah sebanayak 59 unit rumah. Dengan rincian penerima bedah rumah sebagai berikut :

Tabel 4.4

Penerima Kegiatan Bedah Rumah Program Samisake di Kecamatan Depati Tujuh Tahun 2014

\begin{tabular}{cll}
\hline NO & \multicolumn{1}{c}{ NAMA } & \multicolumn{1}{c}{ DESA } \\
\hline 1 & Juarnis & Tebat ijuk \\
2 & Mustopa & Tebat ijuk \\
3 & Perlinawati & Tebat ijuk \\
4 & Gafneri & Lubuk suli \\
5 & Hadita & Lubuk suli \\
6 & Amirudin & Lubuk suli \\
7 & Ratnawati & Tebat ijuk dili \\
8 & Enti Yulita & Tebat ijuk dili \\
9 & Suarni & Tebat ijuk dili \\
\hline
\end{tabular}




\begin{tabular}{|c|c|c|}
\hline 10 & Redi fauzi & KAM \\
\hline 11 & Miswan & KAM \\
\hline 12 & Diana & Kubang agung \\
\hline 13 & Disardi & Kubang agung \\
\hline 14 & Rosna & kubang agung \\
\hline 15 & $\begin{array}{l}\text { Nurjango } \\
\text { Adi }\end{array}$ & Kubang gedang \\
\hline 16 & Rahman & Kubang gedang \\
\hline 17 & $\begin{array}{l}\text { Nurpah } \\
\text { Dahlan }\end{array}$ & Belui \\
\hline 18 & umar & Belui \\
\hline 19 & Santi wani & Belui \\
\hline 20 & Umar talib & Sekungkung \\
\hline 21 & Ridwan & Sekungkung \\
\hline 22 & Timu dijah & Sekungkung \\
\hline 23 & $\begin{array}{l}\text { Sarumai } \\
\text { Badu }\end{array}$ & Koto payang \\
\hline 24 & manap dpt & Koto payang \\
\hline 25 & Sumardi & Koto payang \\
\hline 26 & Hudni & Belui tinggi \\
\hline 27 & Timah Jarah & Belui tinggi \\
\hline 28 & Nurmai & Belui tinggi \\
\hline 29 & $\begin{array}{l}\text { Smaryati } \\
\text { Milson }\end{array}$ & Pahlawan belui \\
\hline 30 & torong & Pahlawan belui \\
\hline 31 & Erliana & Pahlawan belui \\
\hline 32 & Darmalina & Koto tuo \\
\hline 33 & Sedai & Koto tuo \\
\hline 34 & Hendriadi & Koto Tuo \\
\hline 35 & Sukri L & Semumu \\
\hline 36 & Sardiman & Semumu \\
\hline 37 & Kasim & \\
\hline & Bakri & semumu \\
\hline 38 & Nasarudin & Ladeh \\
\hline 39 & Ramli & Ladeh \\
\hline 40 & Hardianto & Baru kubang \\
\hline 41 & Iskar wafi & Baru kubang \\
\hline 42 & Syafrudin & Baru kubang \\
\hline 43 & $\begin{array}{l}\text { Ujudiah } \\
\text { Bahtiaruddi }\end{array}$ & Koto panjang \\
\hline 44 & $\mathrm{n}$ & Koto panjang \\
\hline 45 & Silin Sema & Koto panjang \\
\hline 46 & Damilah & Koto panjang \\
\hline 47 & $\begin{array}{l}\text { Kasibah } \\
\text { Insan }\end{array}$ & Koto simpai \\
\hline 48 & sukman & Koto simpai \\
\hline
\end{tabular}

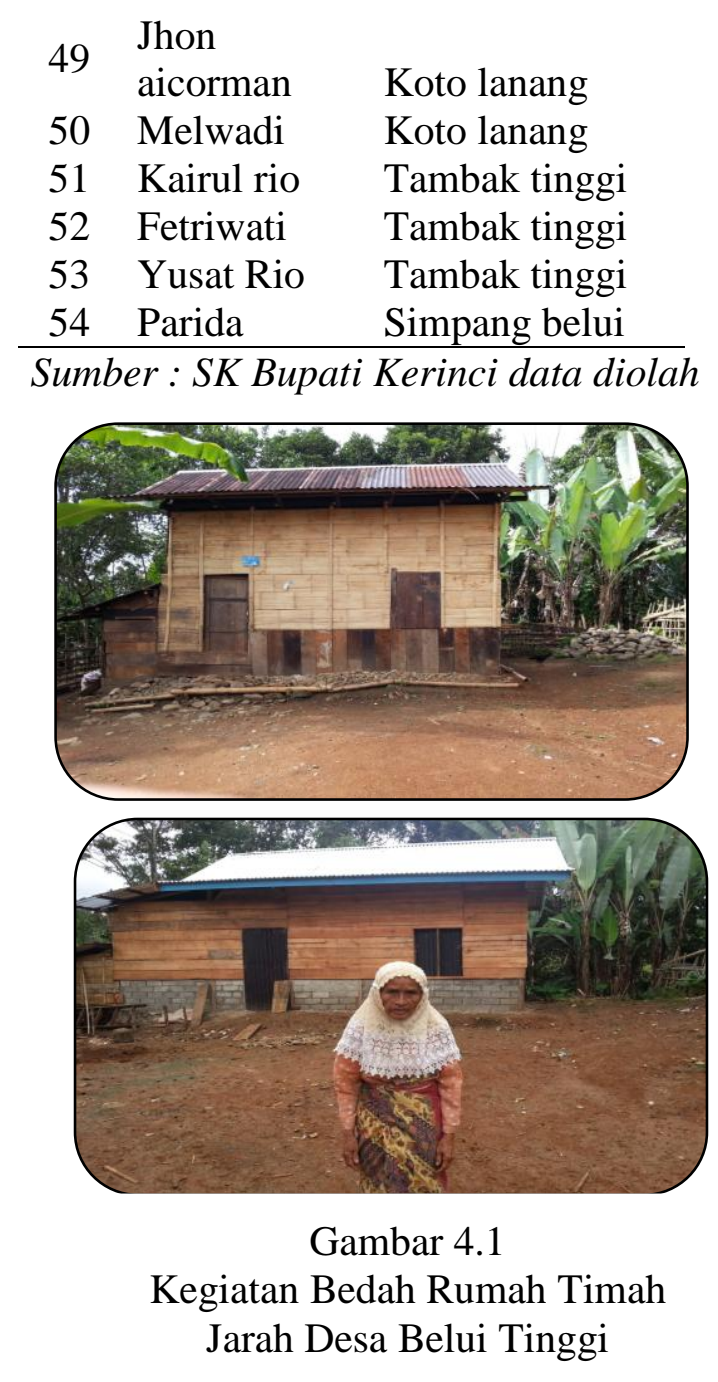

Dari 59 penerima diatas setelah dikonfirmasikan dengan Bappeda Kabupaten Kerinci dinyatakan bahwa semuanya layak menerima bantuan bedah rumah. Dan saat dimintai keterangan Panitia pelaksana Bedah Rumah, bahwa semua penerima telah melaksanakan kegiatan bedah rumah $100 \%$.

\section{Kegiatan Beasiswa}

Kegiatan Beasiswa pada Kecamatan Depati Tujuh pada tahun 2014 dapat sebanayak 59 siswa. Dengan rincian penerima Besiswa sebagai berikut :

Tabel 4.5 
Penerima Kegiatan Beasiswa

Program Samisake di Kecamatan Depati

Tujuh Tahun 2014

\begin{tabular}{|c|c|c|}
\hline NO & NAMA & DESA \\
\hline 1 & Sely Marzelia & Semumu \\
\hline \multirow{2}{*}{2} & Seli Echa & \multirow[t]{2}{*}{ Semumu } \\
\hline & Wahyuni & \\
\hline 3 & Siswanti & Semumu \\
\hline 4 & Reva Juni Yanti & \multirow[t]{2}{*}{ Semumu } \\
\hline \multirow{2}{*}{5} & Gilang Adil & \\
\hline & Fitrawan & Tebat Ijuk \\
\hline 6 & Santri Hidayanti & Tebat Ijuk \\
\hline \multirow{2}{*}{7} & Melani Tasya & \\
\hline & Putri & Ladeh \\
\hline 8 & Arif Herawan & Ladeh \\
\hline 9 & Fajar Al Ghufron & Koto Payang \\
\hline 10 & Sery Marwati & Koto Payang \\
\hline \multirow{3}{*}{11} & Resti Sapitri & Kubang \\
\hline & & Gedang \\
\hline & Anil Chandra & Kubang \\
\hline 12 & \multirow{3}{*}{ Yulian Branzizki } & Gedang \\
\hline 13 & & Kubang \\
\hline & & Gedang \\
\hline 14 & Faldi Zalhabil & Koto Panjang \\
\hline 15 & Sandi Rahman & Koto Panjang \\
\hline 16 & Wiwi Erwina & Koto Panjang \\
\hline 17 & Febsi Murliati & Koto Panjang \\
\hline 18 & Roki Pebrianda & Belui \\
\hline \multirow{2}{*}{19} & Sonya Dwi & \multirow[t]{2}{*}{ Belui } \\
\hline & Manius & \\
\hline 20 & Pawil Sadra & Belui \\
\hline 21 & Dendi Ridho & Belui \\
\hline 22 & Aditya Retri Putra & Belui \\
\hline \multirow{3}{*}{23} & Wawan Andika & \\
\hline & Pratama & Baru Kubang \\
\hline & Yulia Rahmi & \multirow[t]{2}{*}{ Baru Kubang } \\
\hline 24 & Hazmi & \\
\hline \multirow[t]{2}{*}{25} & Winda Jelita & Baru Kubang \\
\hline & Felisia & Kubang \\
\hline 26 & & Agung \\
\hline \multirow{3}{*}{27} & Nelya Despita & Kubang \\
\hline & & Agung \\
\hline & Roby Putra & Kubang \\
\hline 28 & & Agung \\
\hline 29 & Putri Thesya & Koto Lanang \\
\hline
\end{tabular}

\begin{tabular}{|c|c|c|}
\hline & Kurnia & \\
\hline & Anjelia Nanda & Koto Lanang \\
\hline 30 & Putri & \\
\hline 31 & Rahmat Setiawan & Koto Lanang \\
\hline & Herlin Pebriasari & Simpang \\
\hline 32 & & Belui \\
\hline 33 & Kelly Rosanah & Simpang \\
\hline 34 & Edilan Kurniawan & $\begin{array}{l}\text { Simpang } \\
\text { Belui }\end{array}$ \\
\hline 35 & Dimas Pratama & $\begin{array}{l}\text { Tebat Ijuk } \\
\text { Dili }\end{array}$ \\
\hline & Muhammad & Tebat Ijuk \\
\hline 36 & Aqbal & Dili \\
\hline 37 & Oka Satria & $\begin{array}{l}\text { Tebat Ijuk } \\
\text { Dili }\end{array}$ \\
\hline 38 & Fadel Andrea & Belui Tinggi \\
\hline 39 & Djaya Chasuma & Belui Tinggi \\
\hline 40 & Nopriyanto & Belui Tinggi \\
\hline 41 & Ilham Purnama & Tambak \\
\hline 41 & Putra & Tinggi \\
\hline & Nuari Budi Yarto & Tambak \\
\hline 42 & & Tinggi \\
\hline & Beni Juanda & Tambak \\
\hline & M. Perdin & Tinggi \\
\hline 44 & Pradifta & Lubuk Suli \\
\hline 45 & Riko Handika & Lubuk Suli \\
\hline 46 & Anisa Honesti & Lubuk Suli \\
\hline 47 & Ravi Andika & Lubuk Suli \\
\hline & Andres Maulana & Pahlawan \\
\hline 48 & & Belui \\
\hline 10 & Apralio Hidayat & Pahlawan \\
\hline 49 & & Belui \\
\hline & Pandu Rakasima & Pahlawan \\
\hline 50 & & Belui \\
\hline 51 & Vidia Anisa & Kam \\
\hline 52 & Fitri Amartia & Kam \\
\hline & Wahyu Rahmat & \\
\hline 53 & Dani & Sekungkung \\
\hline 54 & Wandi Eka Putra & Sekungkung \\
\hline 55 & Diki Damhuri & Sekungkung \\
\hline & Agnes Oktaviana & \\
\hline 56 & Utari & Koto Tuo \\
\hline & Veno teguh & Koto Tuo \\
\hline 57 & Iswanda & \\
\hline
\end{tabular}




\begin{tabular}{rlr}
\hline & Nocy Revo & Koto Tuo \\
58 & Prasmuti & \\
59 & Nedi Saputra & Koto Simpai \\
\hline \multicolumn{2}{l}{ Sumber : SK Bupati Kerinci data diolah }
\end{tabular}

Untuk siswa SD mendapatkan bantuan sebesar Rp. 750.000,- (tujuh ratus lima puluh ribu rupiah) untuk SMP mendapatkan sebesar Rp. 1.000.000,(satu juta rupiah) untuk SMA mendapatkan sebesar Rp. 1.500.000,(satu juta lima ratus ribu rupiah) dan untuk perguruan tinggi sebesar $\mathrm{Rp}$. $3.000 .000,-$ (tiga juta rupiah).
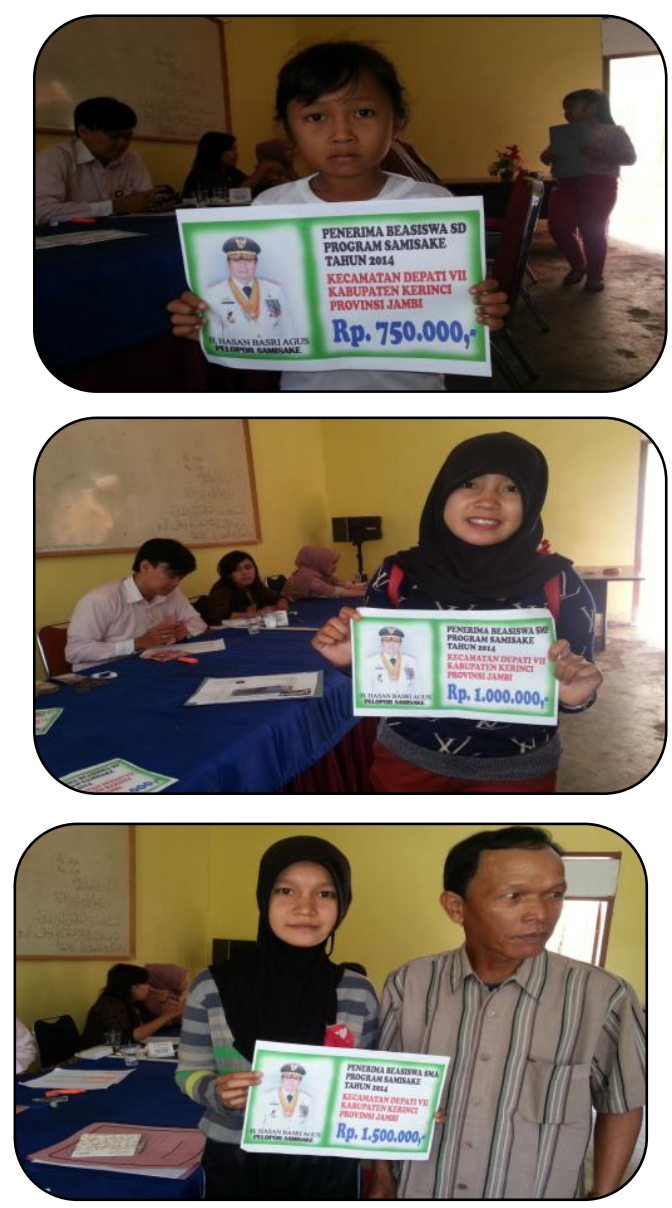

Gambar 4.2

Kegiatan Beasiswa Program Samisake
Dari 59 penerima diatas setelah dikonfirmasikan dengan Bappeda Kabupaten Kerinci dinyatakan bahwa semuanya layak menerima bantuan beasiswa. Dan saat dimintai keterangan Panitia pelaksana Kecamatan, DPPKAD Kabupaten Kerinci, dan BNI Sungai Penuh, bahwa semua penerima telah mendapatkan Bantuan beasiswa sesuai dengan besaran anggaran yang telah ditetapkan.

3. Kegiatan Bantuan Modal

Kegiatan Bantuan Modal pada Kecamatan Depati Tujuh pada tahun 2014 dapat sebanayak 16 Orang. Dengan rincian penerima bantuan modal sebagai berikut :

Tabel 4.6

Penerima Kegiatan Bantuan Modal Program Samisake di Kecamatan Depati Tujuh Tahun 2014

\begin{tabular}{cll}
\hline NO & \multicolumn{1}{c}{ NAMA } & \multicolumn{1}{c}{ DESA } \\
\hline 1 & Eli Marni & Koto Lanang \\
2 & Aryani & Koto Tuo \\
3 & Muharman & Sekungkung \\
4 & Indra Darman & Sekungkung \\
5 & & Pahlawan \\
6 & Yudi Saprianto & Belui \\
7 & Kktriyani & Tebat Ijuk Dili \\
8 & Ifan Saputra & Lubuk Suli \\
9 & Rudi Hartono & Kubanu Agung \\
10 & Radisah & Tebat Ijuk \\
11 & Tisnawati & Belui \\
12 & Edi Hartoni & Belui Tinggi \\
13 & Yenni Susanti & Simpang Belui \\
14 & Sukmin Damin & KAM \\
15 & Elpi Yarneti & Koto Payang \\
16 & Pitriani & Koto Panjang \\
\hline \multicolumn{2}{l}{ Sumber $:$ SK Bupati Kerinci data diolah }
\end{tabular}




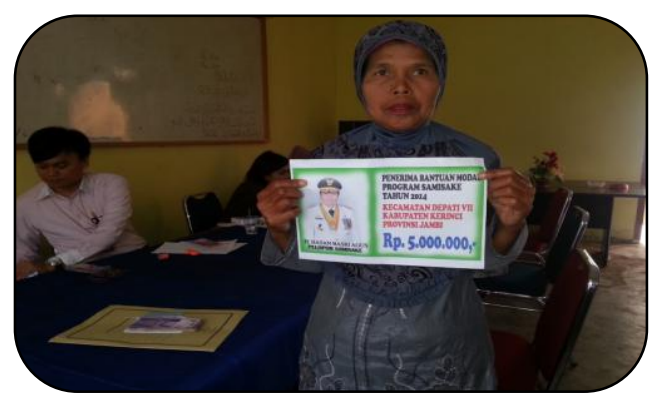

Gambar 4.3

Kegiatan Bantuan Modal Program Samisake

\begin{tabular}{|c|c|c|}
\hline 2 & Nurhaina & KAM \\
\hline & $\begin{array}{l}\text { Anna } \\
\text { Lestarina }\end{array}$ & Ladeh \\
\hline 4 & Deswati & Lubuk Suli \\
\hline 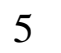 & Huspitar & Baru Kubang \\
\hline 6 & Susilawati & Kubang Agung \\
\hline 7 & Rosmadeli & Kubang Gedang \\
\hline 8 & $\begin{array}{l}\text { Pratiwi } \\
\text { Noflisa }\end{array}$ & Koto Panjang \\
\hline & yawati & Koto Panjang \\
\hline & i Selpia & Koto Payang \\
\hline & Efianti & Tambak tinggi \\
\hline & \& «na Isma & Pahlawan Belui \\
\hline 13 & Minarni & Belui \\
\hline & Negi Pirnama & Koto Simpai \\
\hline 14 & Sari & \\
\hline 15 & Dini Marlina & Sekungkung \\
\hline 16 & Dela & Koto Simpai \\
\hline
\end{tabular}

Sumber : SK Bupati Kerinci data diolah

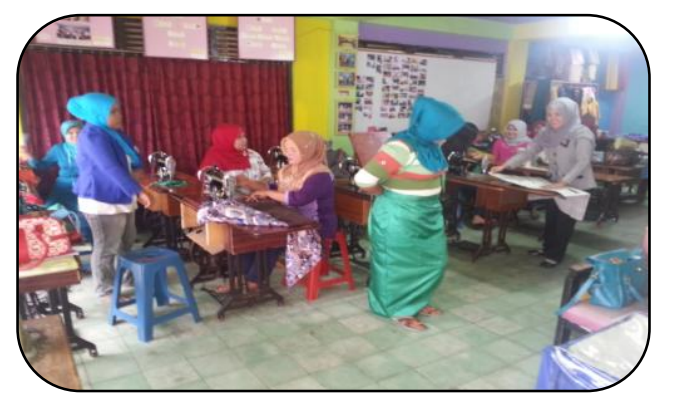

Gambar 4.4

Kegiatan Pelatihan Menjahit Program Samisake

4. Kegiatan Pelatihan

Kegiatan pelatihan pada Kecamatan Depati Tujuh pada tahun 2014 dapat sebanayak 16 0rang. Dengan rincian penerima bantuan pelatihan menjahit sebagai berikut :

Tabel 4.7

Penerima Kegiatan Pelatihan Menjahit Program Samisake di Kecamatan Depati Tujuh Tahun 2014

\begin{tabular}{ccc}
\hline NO & NAMA & DESA \\
\hline 1 & Fusniar & Koto Lanang \\
\hline
\end{tabular}

Dari 16 penerima tersebut diatas setelah dikonfirmasikan dengan Bappeda Kabupaten Kerinci dinyatakan bahwa semuanya layak menerima bantuan Pelatihan. Dan saat dimintai keterangan Panitia pelaksana Kecamatan, BLK Kabupaten Kerinci, bahwa semua penerima telah mendapatkan Pelatihan menjahit sesuai dengan waktu yang telah ditentukan. Dan peserta telah diberikan uang saku dan uang transportasi.

5. Kegiatan Alsintan 
Kegiatan Alsintan pada Kecamatan Depati Tujuh pada tahun 2014 dapat sebanayak 10 Kelompok. Dengan rincian penerima bantuan Alsintan sebagai berikut :

Tabel 4.8

Penerima Kegiatan Alsintan

Program Samisake di Kecamatan Depati

Tujuh Tahun 2014

\begin{tabular}{|c|c|c|}
\hline NO & NAMA & DESA \\
\hline 1 & Ardiansyah & Simpang belui \\
\hline 2 & M. nursal & Simpang belui \\
\hline 3 & $\begin{array}{l}\text { Nemi } \\
\text { desyenti }\end{array}$ & Simpang belui \\
\hline 4 & Mahyuddin & Simpang belui \\
\hline 5 & Naswardi & Simpang belui \\
\hline 6 & Rafliadi & Koto payang \\
\hline 7 & Nora aini & Koto payang \\
\hline 8 & Sanatan & Koto payang \\
\hline 9 & Saprianto & Koto payang \\
\hline 10 & Epen ardi & Kubang agung \\
\hline 11 & Hermen & Kubang agung \\
\hline 12 & Nafrinuddin & Kubang agung \\
\hline 13 & $\begin{array}{l}\text { Eva } \\
\text { syafyanto }\end{array}$ & Kubang agung \\
\hline 14 & M. saher & Koto simpai \\
\hline 15 & Jafrisal & Koto simpai \\
\hline 16 & Mohd. taufik & Koto simpai \\
\hline 17 & Insan sukman & Koto simpai \\
\hline 18 & Herlin & Koto panjang \\
\hline 19 & Yalpari & Koto panjang \\
\hline 20 & Tarmizi & Koto panjang \\
\hline 21 & Husrizal & Koto panjang \\
\hline 22 & Zakardi & Baru kubang \\
\hline 23 & Morizon & Baru kubang \\
\hline 24 & Jufri ahmad & Baru kubang \\
\hline 25 & Asnawi & Baru kubang \\
\hline 26 & Afrial janur & Baru kubang \\
\hline 27 & $\begin{array}{l}\text { Kulisdi } \\
\text { apriyanto }\end{array}$ & Kubang gedang \\
\hline 28 & Afrisal & Kubang gedang \\
\hline 29 & Abasri & Kubang gedang \\
\hline 30 & Eli mustati & Kubang gedang \\
\hline 31 & Aspari & Kubang gedang \\
\hline 32 & Hadi & Tambak tinggi \\
\hline
\end{tabular}

suryanto

33 Saripudin Tambak tinggi

34 Hardiswan Tambak tinggi

35 Syafra alim Tambak tinggi

36 Marita susani Pahlawan belui

37 Mirta sayadi Pahlawan belui

38 Nelwati Pahlawan belui

39 Andi ariawan Pahlawan belui

40 Yuhanis Tebat ijuk

41 Abdullah Tebat ijuk

42 Yusup dpt Tebat ijuk

43 Hermanto Tebat ijuk

Sumber : SK Bupati Kerinci data diolah
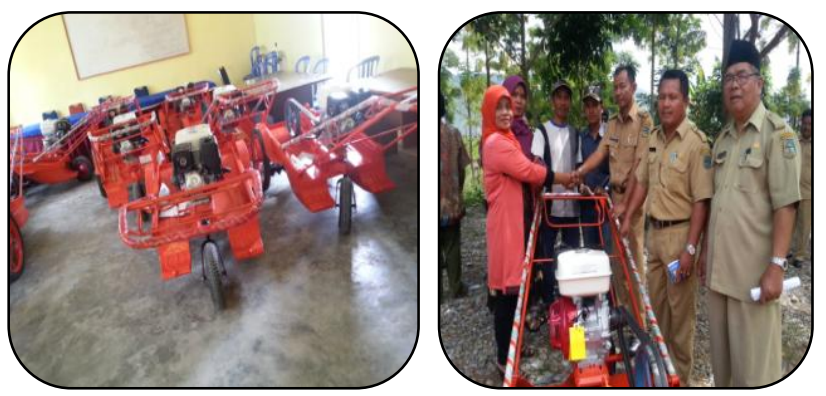

Gambar 4.5

Kegiatan Alsintan Program

Samisake

Dari 10 kelompok penerima tersebut diatas setelah dikonfirmasikan dengan Bappeda Kabupaten Kerinci dinyatakan bahwa semuanya layak menerima bantuan mesin. Dan saat dimintai keterangan Panitia pelaksana Kecamatan, bahwa semua penerima telah mendapatkan Bantuan mesin sesuai dengan tekhnis yang direncanakan.

\section{DAFTAR PUSTAKA}

Adisasmito, Wiko, 2014, Sistem Kesehatan, PT Raja Grafindo Persada, Jakarta. 
Chambers, Robert,2001, Pembangunan Masyarakat Desa, Mulai Dari Belakang, LP3ES, Jakarta.

Danin, Sudarwan, 2000. Pengantar Study Penelitian Kebijakan, Jakarta, Bumi Aksara.

Dunn, N William, 2000. Pengantar Analisis Kebijakan Publik, Edisi Kedua: Gadjah Mada University Press.

Eliza, Y. Adriani, E. Maryanti, S. (2019). The Analysis Return on Investment Education of Married Woman in Indonesia. KnE Social Sciences, 667-688667-688

Ermayenti, E. Heryanto, H. (2019). The Effect Of Competence And Discipline Of Work On Public Satisfaction In The Regional Office Of The Ministry Of Religion In West Sumatera Province With Quality Of Service As An Intervening Variable. Archives of Business Research 7 (7), 69-87

Friedman, John, 2007. Empowerment: The Politics of Alternative Development, Massachusetts, MIT Press.

Hulme, David \& M. Turner, 1990. Sociology of Development : Theories, Policies and Practices. Hertfordshire : Harvester Whearsheaf.

Kartasasmita, Ginanjar, 2001. Pemberdayaan Masyarakat: Konsep Pembangunan yang Berakar pada Masyarakat, Bandung, ITB.
Kartasasmita, Ginandjar. 2001. Pemberdayaan Masyarakat : Sebuah Tinjauan Administrasi. Pidato Pengukuhan Jabatan Guru Besar dalam Ilmu Administrasi pada Fakultas Ilmu Administtrasi.

Kieffer, C.H, 2006. The Emergence of Empowerment : The Development of Participatory Competence Among Individuals in Organizations. Unpublished $\mathrm{PhD}$ dissertation, Univertsity of Michigan . Ann Arbor.

Korten, David C dan Sjahrir, 2001. Pembangunan Berdimensi Kerakyatan, Jakarta, Yayasan Obor.

Kurniawan, H. Heryanto, H. (2019). Effect of Work Discipline and Work Environment on Employee Performance with Work Motivation as an Intervening Variable in Department of Tourism, Youth and Sport of Padang District. Archives of Business Research 7 (7), 88-101

Marlius, D. RD Putra. (2018). Strategi Pengembangan Sulam Bayang. Jurnal Benefita: Ekonomi Pembangunan Manajemen Bisnis Dan Akuntansi. Volume 3. No. 2. Hal. 204-218. http://doi.org/10.22216/jbe.v3i2 .3494

Marzuki. 2002. Metodologi Riset. Yogyakarta: PT. Prasetia Widya Pratama. 
Pedoman Umum Pelaksanaan Program Samisake Provinsi jambi tahun 2014.

Prijono, Onny S. dan Pranarka A.M.W. (ed.). 2003. Pemberdayaan : Konsep, Kebijakan dan Implementasi. Jakarta : Centre for Strategic and International Studies (CSIS).

Putra, RY. Marlius, D. (2019). Pengaruh Pendidikan, Pengalaman Kerja dan Etos Kerja Terhadap Kinerja Pegawai Di KPN Batur. Academic Conference For Management 2.

Putra, EE. (2014). The Effect of Human Capital, Structural and Customer Capital to Performance of Small Medium Enterprises at West Sumatera Province. Business Administration at Jose Rizal University

Selamat, S. Heryanto, H. (2019). Affecting Factors In Employee Performance Koto Baru SubDistrict, Dharmasraya District. Archives of Business Research 7 (7), 142-154

Universitas Brawijaya, Malang, 27 Mei. Kartasasmita, Ginandjar. 1997. Administrasi Pembangunan. Jakarta : Penerbit : LP3ES 